\title{
Notes
}

\section{Transfers of Copyrights for Security Under the New Copyright Act}

The use of copyrights as collateral security for loans was rare until recent decades, ${ }^{1}$ largely because literary and artistic property had little economic significance." The advent of modern means of communication, however, has greatly increased the economic significance of copyrights, ${ }^{3}$ so that today such rights are increasingly important as an actual and potential source of collateral security, particularly in the entertainment industry. ${ }^{4}$ This is a desirable trend, for the right to use property to obtain credit is an important one that should inhere in property created by federal statute no less than in more traditional forms of property.

1. 1 G. Gilmore, Security Interests in Personal Property $\$ 13.3$, at 410 (1965).

2. Kaplan, Literary and Artistic Property (Including Copyright) as Security: Problems Facing the Lender, 19 Law \& Contemp. Prob. 254, 254 (1954).

3. Economic statistics for industries that produce copyrightable material, such as the publishing, greeting card, and motion picture industries, are not readily available, but as early as 1954 the value of the output of such industries exceeded six billion dollars, making the "copyrights industry" nearly as large as the automobile industry, and larger than the mining, banking, or health services industries. Hovse Comm. ON THE JUdicIARY, 86rk CoNg., 1st Sess., Copyright Law Revision Study No. 2, at 28 (Comm. Print 1960). By 1970 , the motion picture industry alone accounted for $\$ 1.5$ billion of the gross national product. B. Kaplan \& R. Brown, Cases on Copyricht 422 (3d ed. 1978).

4. Kaplan, supra note 2, at 255; see Hotse CoMm. ON THE JUdiciary, 89Th CoNG., Ist Sess., Copyright Law Revision P.art 5, at 306 (Comm. Print 1965) (statement of Motion Picture Association of America, Inc.) ("hypothecation" is "very important factor in copyright"). See generally Concoff, Motion Picture Secured Transactions under the Uniform Commercial Code: Problems in Perfection, 13 U.C.L.A. L. Rev. 1214 (1966). Although the Copyright Office does not produce scparate statistics on the use of assignments for security, filings of assignments for sccurity seem to be "increasingly common." Interview with Mary Lyle, Copyright Office Programs Analyst and former Assistant Head of Assignments Section, Library of Congress, Washington, D.C. (Mar. 8, 1978) (notes on file with Yale Law Journal).

5. Frecman, The Copyright as Security, 12 K.AN. ST. B.A.J. 257, 258 (1944). The principle of free transferability of copyrights for security is now embodied in both federal and state law. H.R. REP.. No. 1476, 94th Cong., 2d Sess. 123 (1976), reprinted in [1976] U.S. CoDE CoNG. \& AD. NEws 5738 (new Copyright Act embodies "principle of unlimited alien. ability" of copyright, including by mortgage) [hereinafter cited as HousE REPORT with page citations to [1976] U.S. Code CoNG. \& AD. News]; 1 G. GILMORE, supra note 1, at 290 (policy of Article 9 of U.C.C. is that "all types of personal property . . should be recognized as available for security").

The business that is unable to provide collateral security may have trouble obtaining 
Historically, difficulties of perfecting a security interest in intangible property impeded transfers of copyrights for security, but Article 9 of the Uniform Commercial Code eliminated most of these impediments. ${ }^{6}$ Copyright law itself presented certain difficulties, but observers expected the new Copyright Act to remove these remaining legal obstacles to copyright financing. ${ }^{\top}$

Although the new Copyright $\mathrm{Act}^{8}$ does remove the old obstacles to transfers of copyrights for security, it erects new ones in their place, which jeopardize the financial arrangements for the production of a copyrightable work. Certain of the new provisions, notably the registration requirement, threaten security interests in copyrights with

commercial credit. Almost $70 \%$ of all bank loans to business are secured by commercial property, and small firms are particularly dependent on such loans. P. HUNT, C. WILL1AMS \& G. Donaldson, Basic Business Finance 268 (1971). For businesses whose property consists primarily of copyrights, the use of these copyrights as collateral can be extremely im. portant. See Concoff, supra note 4, at 1227 (U.C.C. category of intangible property is "of crucial importance in motion picture financing").

6. See Nimmer on Copyright $\$ 121.2$ (1976) (ability to create security interest in common law copyright was "screrely circumscribed" under pre-Code law); Freeman, supra note 5 , at 257 (noting reluctance of courts to recognize legitimacy of copyrights as collateral).

Before the acloption of the Uniform Commercial Code, it was uncertain whether the proper security instrument for a copyright was a mortgage or a pledge. Kaplan, supin note 2, at 257-59. The Code does not provide that a copyright cannot be pledged, but it makes clear that a security interest in a copyright cannot be perfected by pledge. Sce U.C.C. \$ 9-106, Comment (copyrights are "general intangibles"); id. \$ 9.302(1) ("general intangibles" not among classes of collateral excluded from general requirement of filing financing statement to perfect security interest) [all citations hercin to L.C.C. refer to 1972 Official Text and Comments]. It was also unclear whether compliance with recording provisions of the Copyright Act would ralidate a mortgage for purposes of state law if local filing provisions were not also complied with. Kaplan, supra note 2, at 259-61. The Code removes this doubt by eliminating the local filing requirement when a federal statute, such as the Copyright Act, provides for filing of security interests. U.C.C. $\$ 9$. $302(3),(4)$.

7. Lncler the old Copyright . Act it was unclear whether a creditor who filed his mort. gage after a statutory "grace period" would defeat a subsequent transferec. See Ditto, Musical Coprright as Collateral in Secured Transactions, 19 ASC.AP Copyricur L. SyMr. 219, 235-30 (1969); Note, Copyright as Collateral in a Secued Transaction, 39 ST. Jown's L. REv. 90, 95-97 (1964). The new Act makes clear that if this creditor is the first to file, he wins eren if he files after the "grace period." See Copyright Act of 1976, 17 L.S.C. app. \$ $20.5(\mathrm{e})(1976)$. It was also unclear under the old law whether assignments of partial ights, e.g., motion picture rights, were true assignments, which could be recorded with the effect of constructive notice, or mercly licenses, which could not. The new Act provides that any right, partial or otherwise, can be assigned and recorded. See id. $\$ 201$ (d)(2) (any right may be transferred); id. $\$ 205$ (a) (any transfer may be recorded).

The new Act also removes the uncertainty about whether a copyright can be pledged. See id. $\$ 204$ (a) ("a transfer of ownership is not valid unless an instrument of conveyancc, ... is in writing").

Finally, by recognizing a statutory copy right from the moment a work of authorship is first fixed in a copy, thereby precmpting the conmon law copyright, the new Act eliminates the need to file two mortgages-one on the common law copyright and one on the statutory coprright. See p. 134 infra; Concoff supra note 4, at 1239.40.

8. Copyright .Irt of 1976. 17 U.S.C. app. $\$ \$ 101-810$ (1976) (effective Jan. 1, 1978). 
subordination to the rights of subsequent transferees, lien creditors, and trustees in bankruptcy. To eliminate these threats and to facilitate secured transactions involving copyrights, this Note proposes an amendment to the new Copyright Act.

\section{Security Transfers of Unregistered Copyrights Under the Old Copyright Act}

The new Copyright Act recognizes a statutory copyright from the moment a work is first fixed in a copy. ${ }^{9}$ Previously, a statutory copyright had subsisted only in a work that had been published with a proper notice of copyright ${ }^{10}$ or, if unpublished, had been registered at the Copyright Office. ${ }^{11}$ Although under the old Act a "common law copyright" existed in works of authorship until they qualified for statutory protection, ${ }^{1: 2}$ the common law copyright was extinguished when the statutory copyright was secured by publication or registration. ${ }^{13}$ An author who had mortgaged a common law copyright there-

9. Id. $\$ 302(\mathrm{a})$ ("Copyright in a work created on or after January 1, 1978, subsists from its creation ...."); id. $\$ 101$ ("A work is 'created' when it is fixed in a copy or phonorecord for the first time; where a work is prepared over a period of time, the portion of it that has been fixed at any particular time constitutes the work as of that time . . .."); id. (" 'Copies' are material objects, other than phonorecords, in which a work is fixed by any method now known or later dereloped, and from which the work can be perceived, reproduced, or otherwise communicated ....")

10. Copyright Act of 1909, 17 U.S.C. $\$ 10$ (1970) (repealed 1976) (“Any person entitled thereto by this title may secure copyright for his work by publication thercof with the notice of copyright required by this title ....) The Copyright Act of 1909 was amended many times before being superseded by the new Act, but this provision and all other provisions cited in this Note remained substantially unchanged until 1976. The copyright law as it existed immediately prior to enactment of the new statute will, for convenience, be referred to as the Copyright Act of 1909 .

11. Id. $\$ 12$ ("Copyright may also be had for the works of an author, of which copies are not reproduced for sale, by the deposit, with claim of copyright, of one complete copy of stuch work ....")

12. Id. $\$ 2$ (nothing in Act "shall be construed to annul or limit the right of the author or proprictor of an unpublished work, at common law or in equity, to prevent the copying, publication, or use of such unpublished work without his consent"); see, e.g., Wheaton v. Peters, 33 L.S. (8 Pet.) 591, 657 (1834) ("That an author, at common law, has a property in his manuscript, and may obtain redress against any one who deprives him of it, ... cannot be doubted"); Biltmore Music Corp. v. Kittinger, 238 F.2d 373, 378 (9th Cir.), cert. denied, 352 L.S. 954 (1956) (composer of musical arrangement held to have "vested property right" therein prior to application for statutory copyright); Loew's Inc. $v$. Superior Court, 18 Cal. 2d 419, 115 P.2d 983 (1941) (apart from statute "law recognizes certain rights of property in the original intellectual products of an author").

13. E.g., Wheaton v. Peters, 33 L.S. (8 l'et.) 591,657 (1834) (claimant in infringement suit could find protection only under copyright statute since publication had divested author of common law copyright); White v. Kimmcll, 193 F.2d 744 (9th Cir. 1952) (common law copyright destroyed by author's general publication of manuscript). Curiously, the only reported case in which the destruction of interests in copyright, other than those of the owner, is considered is Daly v. Walrath, 40 A.D. 220,57 N.Y.S. 1125 (1899) (licensee's common law rights destroyed by author's publication of work even though publication was in violation of contract with licensec). 
fore had the power to destroy the mortgagee's collateral by registering or publishing his work and, thereby, to subordinate the mortgagee's security interest to the interests of transferees of the statutory copyright. ${ }^{14}$

Under the old Copyright Act, the risk of subordination arose only if the security interest was taken before the statutory copyright had been secured. Yet it is during this period, while the work is being produced, that credit may be most needed. Independent motion picture producers, for example, have always depended on outside financing during production. ${ }^{15}$

14. Two other commentators have recognized this possibility, see Concoff, supra note 4, at 1237; Note, supra note 7, at 97 , but thus far no case in which a mortgagee has lost his interest to another party in this way has been reported. Typically, an assignment of a copyright is subordinated to a later interest because it has not been properly recorded. This was the case in Photo-Drama Motion Picture Co. v. Social Uplift Film Corp., 220 F. 448 (2d Cir. 1915), where Kauffman had assigned all dramatic rights in a book, including motion picture rights, to Totten. Kauffman later assigned the same motion picture rights to Photo-Drama, which was informed that the assignment to Totten did not include motion picture rights. Photo-Drama recorded its assignment and therefore had rights superior to those of Totten, who had not recorded. For other examples of multiple assignments, see, e.g., Venus Music Corp. v. Mills Music, Inc., 261 F.2d 577 (2d Cir. 1958); Kenya Music, Inc. v. Warner Bros., 391 F. Supp. 1228 (S.D.N.Y. 1975).

15. I A. Lindley, Entertainment, Publishing and the ARTs: Agreements and the Law 298 (Supp. 1977) (in past, independent producers were dependent on distributors for financing; now they are turning to investment houses, venture capital corporations, and other sources). For a sample of the wide array of financial sources available to motion picture producers, see Setlowe, Hollywood's New Financial Tricks, in THE MOvie Business: American Film Industry Practice 53 (1972). The motion picture industry's need for outside financing should continue to grow, due both to the expanding role of the independent producer and to the emergence of sources of new demand for film entertainment. See Crandall, The Postwar Performance of the Motion-Picture Industry, 20 ANTITRUST BULL. 49, $51-52$ (1975).

Outside of the motion picture industry, lending on the sccurity of a copyright to unpublished work is not unknown, see Richcar Music Co. v. Towns, 53 A.D.2d 501, 505 n.5, 385 X.Y.S.2d 778, $781 \mathrm{n.5}$ (1976), but it is comparatively rare. The lack of proven value in unpublished written and musical works has been the common explanation for the infrequent use of copyrights as collateral, see Ditto, supra note 7, at 237; Note, supra note 7, at 97-98, but this explanation fails to account for copyright-secured lending in the motion picture industry, since films are also difficult to value prior to release, Howe, Bankers and Movie-Makers, in The Movie Business: Americax Film Ivdustry Practice, supra, at $\mathbf{5 7 . 5 8}$.

A better explanation for the comparative lack of copyright-secured financing in other industries may be found in the unique capital requirements of motion picture production. The work of an individual composer or author requires little capital investment, particularly if he is willing to live modestly until the work is published; a motion picture, however, requires props, film, and the work of numerous persons who are unlikely to be willing to defer wage claims until the picture is completed and carning profits. Since the publishing inclustry can therefore operate without large advances of funds, it can, unlike the motion picture industry, afford to avoid the legal problems inherent in copyright production financing.

If the legal problems were resolved, however, writers and composers of stature, whose unpublished works in progress would be valuable, might be tempted to finance their work with loans secuned by the copyright to such work for the same reason that inde- 
The practice of motion picture creditors under the old Copyright Act was to file a mortgage of the common law copyright to the photoplay at the appropriate state records office before advancing funds for production. ${ }^{10}$ The accretion of portions of the picture as production proceeded amounted to the addition of after-acquired property to which a perfected security interest automatically attached.17 Upon completion of production, a statutory copyright was secured by registering the photoplay at the Copyright Office, where a mortgage of the statutory copyright was then recorded to perfect the security interest in the new copyright. ${ }^{18}$ The danger to the creditor was that, if the producer secured a statutory copyright without notifying the creditor, then another transferee might be the first to record an interest therein. ${ }^{19}$ If the transferee took his interest in good faith, then the interest of the creditor would be subordinated. ${ }^{20}$

pendent motion picture producers turned to this pattern of financing: to enhance their artistic independence by securing greater financial independence from the corporations that distribute and sell their work, see Nelson, The Independent Producer, 254 ANNALs 49, 55 (1947); Picker, The Film Company as Financier/Distributor, in ThE Movie Business: American Film Industry Practice, supra, at 95-96.

Another candidate for copyright production finance, one outside the traditional copyright industry, is the rapidly growing computer software business. Although software companies originally produced specialized products for a few large customers, they have begun to develop inventories of programs that can be sold or leased to many customers. Elliot, Thinking Big, Barrons, Sept. 18, 1967, at 3; Software Marketplace Reflects Realignment of Users, 3 Computekworld 83 (1969). A statutory copyright in computer programs has been recognized since 1964, Copyright Registration for Computer Prograns-Announcement From the Copyright Office, 11 Buls. Copyrigit Soc'y 361 (1964), and the use cf individual programs by many customers will increase the importance of copyright protection and the value of the copyright as commercial property. Since a single program may cost as much as S1 million to develop, THE Economist, April 22, 1978, at 106, outside financing may be necessary. The source, whether a commercial lender or a large customer, of funds to develop a program might find it prudent to secure its loan with the copyright to the program. Concerning the size of the software industry, see Boehm, Softuare and its Impact: A Quantitative Assessment, Datamation, May 1973, at 48 (industry accounts for over $\$ 10$ billion of gross national product).

16. Concoff, supra note 4, at 1236. For an example of such an arrangement, see Carnegic Prods., Inc. v. Commissioner, 59 T.C. 642, 645 (1973), and for the banker's point of view, see Howe, suppra note 15.

17. See U.C.C. \$ 9-204(1) (" $[A]$ security agreement may provide that any or all obligations cosered by the security agreement are to be sccured by after-acquired collateral"); Concoff, supra note 4 , at $1236-37$.

18. Concoff, supra note 4 , at 1236-37.

19. See note 14 supra; Concoff, supra note 4 , at 1237 . Concoff has speculated that the gap betwecn registration and recording might be eliminated by recording a mortgage with an after-açuired property clause at the Copyright Office before advancing funds. He cautioned, however, that there was no authority for the validity of mortgages executed prior to the existence of the statutory copyright. Id. at 1237-38.

20. Copyright Act of 1909,17 U.S.C. $\$ 30$ (1970) ("Every assignment of copyright shall be recorded in the copyright office ... in default of which it shall be void against any subsequent purchaser or mortgagee for a valuable consideration, without notice, whose assignment has been duly recorded.") 


\section{Security Transfers of Unregistered Copyrights Under the New Copyright Act}

Under the old Copyright Act, transfers of pre-registration, common law copyrights were vulnerable because the common law copyright was extinguished when the statutory copyright was secured by registration.21 The new Copyright Act abolishes the common law copyright, ${ }^{22}$ provides statutory copyright protection from the moment a work is first fixed in a copy, ${ }^{23}$ and does not require registration as a condition of protection. ${ }^{24}$

Transfers of statutory copyright can therefore now be effected before registration, and pre-registration transferees no longer need fear the loss of their collateral upon registration; nevertheless, pre-registration security interests in copyrights are more vulnerable than ever to subordination.

\section{A. Subordination Under the New Copyright Act}

As between two transferees of an interest in a copyright, the new Copyright Act gives priority to the first to record his transfer in "the manner required to give constructive notice." ${ }^{25}$ Although the new Act provides that "any transfer of copyright or other document pertaining to a copyright may be recorded at the Copyright Office," ${ }^{26}$ recording a document gives constructive notice of its contents only if two requirements are met. The document must identify the work so that, once the

21. See pp. 127-28.

22. The Act states:

[A]ll legal or equitable rights that are equivalent to any of the exclusive rights within the general scope of copyright ...., are governed exclusively by this title. [After January 1, 1978], no person is entitled to any such right or equivalent right in any such work under the common law or statutes of any state.

Copyright Act of 1976, 17 U.S.C. app. $\$ 301$ (a) (1976).

23. See note 9 supra.

24. Copyright Act of 1976, 17 U.S.C. app. $\$ 408$ (a) (1976) ("registration is not a condition of copyright protection"). Registration remains important for some purposes. See, e.g., $i d$. $\$ 411$ (registration is prerequisite to infringement suit).

25. Id. $\$ 205(\mathrm{e}):$

As between two conflicting transfers, the onc executed first prevails if it is recorded, in the manner required to give constructive notice under subsection (c), within one month after its execution in the United States or within two months after its execution outside the United States, or at any time before recordation in such manner of the later transfer. Otherwise the later transfer prevails if recorded first in such manner, and if taken in good faith, for valuable consideration or on the basis of a binding promise to pay royalties, and without notice of the earlier transfer.

26. Id. $\$ 205(\mathrm{a})$ :

Any transfer of copyright ownership or other document pertaining to a copyright may be recorded in the Copyright Office if the document filed for recordation bears the actual signature of the person who executed it, or if it is accompanied by a sworn or official certification that it is a true copy of the original, signed document. 
document is indexed, it will be revealed by a reasonable search under the title or registration number of the work, ${ }^{27}$ and the work itself must be registered. ${ }^{28}$ Together, these requirements have the effect of denying constructive notice status to a recorded document transferring copyright ownership unless third parties are put in a position to trace ownership through the title index, commencing with the original, registering owner. ${ }^{29}$

Third parties are therefore not on constructive notice of security interests in a copyright, even if recorded, until the copyright is registered. If two transferees record their interests before registration, the earlier transferee, even if he is the first to record, cannot be certain of priority, for it is not clear that he is the first to record in "the manner required to give constructive notice." ${ }^{30}$ A pre-registration transferee, moreover, risks that the author will fraudulently or mistakenly register the work under a title different from the title shown in the document recorded by the transferee. If this happens, the interest of the preregistration transferee will be inferior to that of any subsequent good faith transferee who does record under the registered title, even though the latter records later in time. ${ }^{31}$

To ensure his priority over subsequent transferees, a creditor should therefore insist that the work be registered before he advances funds and then refer to the registration number or registered title in the

\section{Id. $\$ 205(\mathrm{c})$ :}

Recordation of a document in the Copyright Office gives all persons constructive notice of the facts stated in the document, but only if-(1) the document, or material attached to it, specifically identifies the work to which it pertains so that, after the document is indexed by the Register of Copyrights, it would be revealed by a reasonable search under the title or registration number of the work; and (2) registration has been made for the work.

28. Id.

29. See House Comm. on the Judiciary, 89 th Cong., Ist Sess., Copyright law Revision PAkT 6, at 77 (Comm. Print. 1965) (Copyright Act adds "another condition for according a recorded document the effect of constructive notice, that registration for the work has been male. This would establish the basis of the copyright covered by the document, and would enable persons searching the records to trace title to the copyright from the original owner.")

30. Copyright Act of 1976,17 U.S.C. app. $\$ 20 \check{5}(\mathrm{c})$ (1976), quoted in note 25 supra.

31. Consider the following hypothetical case. $S$ plans to produce a movie entitled What You Will. To finance production, he borrows from $A$ and gives the copyright as collateral. $A$ immediately and properly records the security agrecment, which identifies the movicto-be by its title What you Will. As production proceeds, $S$ also borrows money from $B$, again giving the copyright as collateral. $B$ is told that the movie is to be entitled Twelfth Night. $B$ promptly and properly records the security agreement. When the movie is completed, $S$ registers it under the title Twelflh Night. Since $A$ 's security agreement would not be revealed by a reasonable search under the title or registration number of the work, his recordation does not give constructive notice, whereas $B$ 's recordation does. See id. $\$ 205(\mathrm{c})$, quoted in note 27 supra. $B$ therefore has priority over $A$. See id. $\$ 205(\mathrm{e})$, quoted in note 25 supra. 
record of transfer. This precaution, however, is not available to the creditor who lends to enable completion of the work, for registration is impractical, if not impossible, until the work is completed. The Copyright Office may refuse to register an uncompleted work. ${ }^{32}$ Furthermore, the copyright to the portions of the work produced after registration would not be covered, ${ }^{33}$ so that the creditor would not be fully protected unless he went through the costly and otherwise senseless process of continually re-registering the work throughout its production. ${ }^{34}$

\section{B. Subordination Under Article 9}

In order to perfect a security interest in intangible property such as copyright, a creditor ordinarily must file in a state filing office an Article 9 "financing statement" that identifies the creditor, the debtor, and the collateral, ${ }^{35}$ but, since the Copyright Act provides for recording of security transfers and for priority among transferees, state regulation of secured transactions in copyrights may be preempted. Although there has been little litigation to mark the boundary between federal and state law in this field, at least two points are clear. First, both the old and new Copyright Acts require that transfers for security be in writing ${ }^{36}$ and that they be recorded at the Copyright

32. A photoplay, for example, will be registered only when it has reached a stage of completion such that it tells "a connected story." 37 C.F.R. $\$ 202.15$ (a) (1977).

33. A work may be registered at any time during the subsistence of the copyright, Copyright Act of 1976,17 U.S.C. app. $\$ 408$ (a) (1976), and statutory copyright subsists only in work fixed in a copy, see note 9 supra. Thus, a registration that purports to cover later additions to the work extant at the time of registration would be without effect as to those additions. The later and larger work that included the additions would be a "derivative work" of the portion already registered, see Copyright Act of 1976, 17 U.S.C. app. $\$ 101$ (1976) ("A work consisting of editorial revisions, annotations, claborations, or other modifications which, as a whole, represent an original work of authorship, is a "derivative work." "), and the copyright in the added material would be "independent" of the copyright in the preexisting work, see id. $\$ 103(\mathrm{~b})$.

34. The practice has been to register only when the work is completed. See Concoff, supra note 4 , at 1236.

35. See U.C.C. $\$ 9.402$ (I) (formal requisites of financing statement). An Article 9 security interest is perfected "when it has attached and when all of the applicable steps required for perfection have been taken." Id. $\$ 9.303(1)$. The requirements for attachment, specified in $\$ 9-203$ of the U.C.C., are of no concern here. The applicable step for perfection of a security interest in a copyright is the filing of a "financing statement" in the appropriate public office; this is true for all "general intangibles," since such collateral does not fall under any of the exceptions to Article 9's gencral filing requirement. See id. \$ 9-106, Comment (copyrights are general intangibles); id. $\$ 9-305$, Comment 1 (general intangibles perfected only by filing).

36. Copyright Act of 1976, 17 U.S.C. app. $\$ 204$ (a) (1976) ("A transfer of copyright ownership, other than by operation of law, is not valid unless an instrument of conveyance, or a note or memorandum of the transfer, is in writing ...."); Copyright Act of 1909, 17 U.S.C. $\$ 28$ (1970) (repealed 1976) ("Copyrights secured under this title . . may be ... mortgaged by an instrument in writing ....") 
Office in order to achieve priority over certain other transfers. ${ }^{37}$ State law cannot eliminate these recording requirements or reverse the established priority. Second, copyright law does not preempt all security law concerning copyrights. In the case of Republic Pictures Corp. $v$. Security-First National Bank of Los Angeles, ${ }^{38}$ decided under the old Copyright Act, the court held that a federal court did not have jurisdiction to foreclose a mortgage of a copyright. ${ }^{39}$ The court reasoned that questions of copyright assignment did not arise under a federal statute even though the copyright itself originated under one.40 Professor Gilmore, noting that " "[f]ederal law is generally interstitial in its nature" " and " "builds upon legal relationships established by the states, altering or supplanting them only so far as is necessary for [its] special purpose," "11 takes Republic Pictures to stand for the proposition that federal copyright law preempts state security law only in the limited areas of recording and the effect of recording on priority. ${ }^{42}$

If Congress had enacted a comprehensive security statute for copyrights, ${ }^{43}$ federal preemption would of course be complete. The new Copyright Act, however, is far from comprehensive. It makes no reference at all to the perfection of security interests or to the effect of perfection on priorities, and its priority rule only works in situations in which all claimants are transferees and in which at least one has recorded in "the manner required to give constructive notice." 44 When the new Copyright Act is silent on priority, as it is, for example, between two security transferees of an unregistered copyright ${ }^{45}$ or between a security transferee and a lien creditor, Article 9 governs the rights of a copyright-secured creditor. ${ }^{46}$

37. Copyright Act of 1976, 17 U.S.C. app. $\$ 205(\mathrm{e})$ (1976), quoted in note 25 supra; Copyright Act of 1909, 17 U.S.C. $\$ 30$ (1970) (repealed 1976), quoted in note 20 supra.

38. 197 F.2d 767 (9th Cir. 1952).

39. Id. at 768. Republic Piclures continues to be the law under the new Copyright Act, since Congress rejected a federal system of mortgage foreclosure, House RePort, supra note 5 , at 5738 , that had been proposed by the motion picture industry, House CoMm. on THE Judtctary, 89Th CoNG., Ist Sess., supra note 4, at 306 (statement of Motion Picture Association of America, Inc.) (consideration should be given as to "whether a uniform federally enforceable system of forcclosure might be spelled out in the copyright statute"). 40. 197 F.2d at 770 .

41. 1 G. GilMore, supra note 1 , $\$ 13.1$, at 402 (quoting H. HART \& H. WEChSLER, ThE Federal Courts aNd the Federal. SYSTEM 435 (1953)).

42. Id. $\$ 13.3$, at 415 .

43. The most nearly comprehensive federal security statute is the Ship Mortgage Act, 46 U.S.C. $\$ \$ 911.961$ (1970). 1 G. GiLMoRE, supra note 1 , $\$ 13.2$, at 405 . See generally G. Gilarore \& C. Black, Tire LAW of Admiralty 586-817 (1957).

44. Copyright Act of 1976, 17 U.S.C. app. $\$ 205($ e) (1976).

45. See p. 131 supra.

46. The case of In re Leslic-Judge Co., 272 F. 886 (2d Cir. 1921), has been taken to hold the contrary, i.e., that security interests in copyright can only be perfected by recording at the Copyright Office. See 1 G. Gilwore, supra note 1, $\$ 13.3$, at 415 . In Leslie-Judge, a 
The Uniform Commercial Code might therefore have provided that, in order to perfect a security interest against subsequent lien creditors, a copyright creditor must follow Article 9's procedures for filing a financing statement in a state filing office. Instead, section 9-302 provides that compliance with federal statutes that have their own filing provisions is "equivalent to the filing of a financing statement under this Article, and a security interest in property subject to the statute ... can be perfected only by compliance therewith . . . "4i Because of this provision, creditors are spared a double filing-a state filing to perfect against lien creditors under Article 9 and a federal filing to obtain priority over subsequent transferees under the Copyright Act.

In order to comply with the new Copyright Act, the creditor must look to its general filing requirements, since the Act does not contain any special requirements for filings pursuant to state security law. The Act provides generally that "any ... document pertaining to a copyright may be recorded," provided only that the document be signed by the party executing it. ${ }^{48}$ There is no requirement that the copyright be registered.49 A creditor could therefore meet the minimum filing requirements of the new Copyright Act without putting third parties on constructive notice, since filing a document at the Copyright Office gives constructive notice of its contents only if it identifies a registered copyright. ${ }^{50}$ It would be an odd result if such a filing were made the equivalent of an Article 9 filing by section 9-302, since the purpose of filing security interests is to give notice to the public. ${ }^{51}$

The Comments to section 9-302, however, indicate that, for purposes of perfecting a security interest, compliance with the Copyright Act requires more than a mere recording. Comment 1 states that the transactions described in section 9-302(3) are those "where suitable alternative systems for giving public notice are available." 52 The drafters of Article 9 apparently anticipated that compliance with the

mortgage of various properties, including copyrights, was invalidated on several grounds, including a failure to record at the Copyright Office. $272 \mathrm{~F}$. at 888 . Although Professor Gilmore cautions that the statement in Leslie-Judge that copyrights "can be mortgaged only under the federal copyright law," id., was not a "reasoned conclusion," 1 G. GILMORE, supra note $1, \S 13.3$, at 412 , he describes the case as "soundly decided," $i d$. at 415 . This description is debatable. See Note, supra note 7 , at 93 . Neither the old nor the new Act makes recording a condition of a mortgage's validity other than against a specific and limited class of transferees. See notes $20 \& 25$ supra.

47. U.C.C. $\$ 9-302(4)$.

48. Copyright Act of 1976,17 U.S.C. app. $\$ 205$ (a) (1976).

49. Id. \$ 408(a); see note 24 supra.

50. Id. \$ 205(c); see pp. 131-32 supra.

51. P. Coogan, W. Hogan, \& D. Vagts, Secured Transactions under the Unifokm Commercial Code $\$ 601[3]$; 1 G. Gilmore, supra note 1 , $\$ 15.3$, at $471-80$; see U.C.C. \$ 9402, Comment 2 (\$ 9.402 adopts "system of 'notice filing" ").

52. U.C.C. $\S 9 \cdot 302$, Comment 1 . 
federal statutes to which the section refers would give adequate notice. Accordingly, Comment 8 specifically excludes the Assignment of Claims Act from the application of section $9-302^{53}$ because its filing system was not "designed to give notice to creditors." ${ }^{4}$

The alternative system for giving public notice under the new Copyright Act is section 205, which requires, for constructive notice of a copyright transfer, not only that the transfer be recorded but also that the work itself be registered.j5 Compliance with the Copyright Act for the purposes of section 9-302 will therefore entail both registration and recording. This creates a problem for the creditor financing the production of a copyrightable work, such as a motion picture. Although he may file a security agreement at the Copyright Office before making his loan, his security interest remains unperfected until the work being financed is completed and registered. Until then, his rights in the collateral are subordinated by Article 9 to the rights of lien creditors, transferees for value without notice, and prior-attaching secured creditors. ${ }^{56}$

\section{Security Transfers of Copyright Under the Bankruptcy Act}

In addition to frustrating the efforts of copyright-secured creditors to obtain priority under the Copyright Act and perfect their interests under Article 9, the priority and recording provisions of the new Copyright Act expose these security interests to avoidance in bankruptcy.

\section{A. Avoidance Under Sections $70(c)$ and 60(b)}

A security interest in a copyright remains unperfected until the underlying work is completed and registered, ${ }^{5 t}$ and, while the interest

53. See id., Comment 8 ("An assignec of a claim against the United States, who must of course comply with the Assignment of Claims Act, must also file under this Article in order to perfect his security interest against creditors and transferees of his assignor.")

54. 1 G. GiLMore, supra note 1 , $\$ 19.10$, at 547 .

55. Copyright Act of 1976,17 U.S.C. app. $\$ 205$ (c) (1976). Under the old Copyright Act, which was in effect when Article 9 was drafted and enacted, recording a transfer served to give constructive notice to all third persons of the facts disclosed in the recorded instrument, Holse Comm. oN the Jtdiciary, 87th Cong., Ist Sfss., Copyright Law Revision 96 (Comm. Print 1961), but under the old Act, there was no statutory copyright at all without registration (or publication with notice), so that the old provisions regarding constıuctive notice were functionally equivalent to the new ones, i.e., in effect both registration and recordation were required to give constructive notice of a transfer of statutory copyright (to unpublished work).

5i. L.C.C. \$ 9-301(1). C'nperfected sccurity interests are, inter alia, subordinate to the rights of (a) persons entitled to priority under Section 9.312, such as holders of priorattaching unperfected sccurity interests under $\$$ 9-312(5)(b); (b) persons who become lien creditors before the sccurity interest is perfected; and (c) transferees to the extent that they give value without knowledge of the security interest and before it is perfected. Id.

57. See pp. 132-35 supra. 
is unperfected, it is subordinate to the rights of subsequent lien creditors. ${ }^{58}$ Under section 70 (c) of the Bankruptcy Act, ${ }^{59}$ the trustee in bankruptcy has the status of a lien creditor on the eve of bankruptcy; he can therefore avoid a security interest in a copyright if the bankruptcy petition is filed before registration. ${ }^{00}$

Although the security interest will become perfected when the underlying work is completed and registered, under certain circumstances the interest will continue to be vulnerable to avoidance under section 60(b) of the Bankruptcy Act. Section 60 empowers the trustee in bankruptcy to avoid transfers made by an insolvent debtor during the four months preceding bankruptcy if the transfer was made "on account of an antecedent debt" and if the effect of the transfer was to enable the transferee to obtain a greater percentage of his debt than another creditor of the same class. ${ }^{61}$

Under section 60 , a transfer for security is deemed to occur at the point in time when a subsequent lien creditor can no longer gain superior rights over the transferee. ${ }^{62}$ For transfers of general intangibles, including copyrights, a proper Article 9 filing usually marks that point in time, ${ }^{63}$ and for transfers of copyrights, a proper Article

58. U.C.C. $\$ 9.301(1)$.

59. Bankruptcy Act $\$ 70(c), 11$ U.S.C. $\$ 110(c)$ (1976) ("The trustee shall have as of the date of bankruptcy the rights and powers of: (1) a creditor who obtained a judgment against the bankrupt upon the date of bankruptcy, whether or not such a creditor exists ....")

60. See 2 G. GILmore, supra note $1, \S 45.3 .2$. (consequences of $\$ 70$ (c) to secured creditors before and after enactment of Article 9); J. White \& R. Summers, Handbook of THE LAW UNDER THE UNIFORM COMMERCIAL CODE $\$$ 24-3 (1972) (rights of trustee under $\S 70(c))$.

61. Bankruptcy Act $\S 60(a)$, (b), 11 U.S.C. $\S 96(a)$, (b) (1976). Two other conditions must also be met: the debtor must be insolvent at the time of transfer and the creditor must have reasonable cause to believe that the debtor is insolvent at that time. Id.; see 2 G. Gilmore, supra note 1, $\$ 45.3 .3-.6$; J. White \& R. Summers, supra note $60, \S 24-4$.

62. Bankruptcy Act $\$ 60(a)(2), 11$ U.S.C. $\$ 96(a)(2)(1976)$ :

[A] transfer of property other than real property shall be deemed to have been made or suffered at the time when it became so far perfected that no subsequent lien upon such property obtainable by legal or equitable proceedings on a simple contract could become superior to the rights of the transferee.

63. See In re King-Porter Co., 446 F.2d 722 (5th Cir. 1971) (transfer of security interest deemed to have occurred for purposes of $\$ 60$ (a)(2) of Bankruptcy Act on date of filing of security interest); DuBay v. Williams, 417 F.2d 1277, 1288 (9th Cir. 1969) (because secured creditor filed financing statement before four month period preceding bankruptcy, his "security interest is immune from the trustee's preference challenge"); Grain Mcrchants v. Union Bank and Sav. Co., 408 F.2d 209, 212 (7th Cir.), cert. denied, 396 U.S. 827 (1969) (security interest in accounts receivable "so far perfected' when . . . financing statements were filed ... that [transfer of security interest] must be deemed to have been made then").

The Bankruptcy Act provides for a twenty-one day grace period in which to make the filing. Bankruptcy Act $\$ 60(a)(7)(I), 11$ U.S.C. $\$ 96(a)(7)(I)$ (1976). Professor Gilmore concludes that this grace period would also apply to filings under federal statutes like the Copyright Act. 2 G. GiLMore, supra note 1, $\$ 45.8$, at 1329. 
9 filing entails registration. ${ }^{64}$ Thus, security transfers of copyrights will be deemed to occur at the later of registration or recording and will be on account of antecedent debt with respect to funds advanced prior to registration. Not only, therefore, is the interest of the copyright production creditor voidable if bankruptcy occurs before registration; under some circumstances, it is also subject to avoidance if bankruptcy occurs within four months thereafter.

\title{
B. Avoidance Under Section 60(a)(6)
}

The provisions of Article 9 that confer priority on perfected security interests over subsequent liens and other interests ${ }^{65}$ must of course give way to the priority provisions of the new Copyright Act. ${ }^{\circ 6}$ The latter provide that the interest of a transferee who has not recorded in a manner that gives constructive notice is subordinate to the interest of a subsequent, good faith transferee who has done so. ${ }^{67}$ Section $60(a)(6)$ of the Bankruptcy Act invalidates a security interest if the secured party fails to take an "overt action" that is a precondition of the security interest's "full validity against third persons other than a buyer in the ordinary course of trade." 68 Since the Copyright Act makes registration a precondition of the priority rights of copyright-secured creditors against subsequent good faith transferees (a category that includes "persons other than a buyer in the ordinary course of trade"), the bankruptcy court may invoke section $60(a)(6)$ to deny recognition to

\author{
64. See p. 132 supra. \\ 65. U.C.C. $\$ \$ 9-312$ to -315 . \\ 66. Copyright Act of 1976, 17 U.S.C. app. $\$ 205(\mathrm{e})$ (1976). \\ 67. The latter interest must be taken in good faith, for valuable consideration, and \\ without notice of the former. $I d$. \\ 68. Section 60(a)(6) of the Bankruptcy Act, 11 U.S.C. $\$ 96(a)(6)$ (1976), provides: \\ The recognition of equitable liens where available means of perfecting legal liens \\ have not been employed is hereby declared to be contrary to the policy of this section. \\ If a transfer is for security and if $(A)$ applicable law requires a signed and delivered \\ writing, or a delivery of possession, or a filing or recording, or other like overt action \\ as a condition to its full validity against third persons other than a buyer in the \\ ordinary course of trade claiming through or under the transferor and (B) such overt \\ action has not been taken, and (C) such transfer results in the acquisition of only an \\ equitable lien, then such transfer is not perfected within the meaning of paragraph \\ (2) of this studivision. Notwithstanding the first sentence of paragraph (2) of this \\ subdivision, it slall not suffice to perfect a transfer which creates an equitable lien \\ such as is described in the first sentence of this paragraph, that it is made for a \\ valuable consideration and that both partics intend to perfect it and that they take \\ action sufficient to effect a transfer as against liens by legal or equitable proceedings \\ on a simple contract....
}

This section has been interpreted as authorizing avoidance of transfers that could have been perfected against third parties, but were not, even if under state law they were perfected against subsequent licns. See 2 G. Gilsore, supra note $1, \S 45.7$, at 1324 . 
security interests in copyrights if bankruptcy occurs before the underlying work is registered. ${ }^{69}$

\section{Avoidance Under the Proposed Bankruptcy Reform Act}

Under the present Bankruptcy Act, a security transfer is deemed made when a proper Article 9 filing has occurred.70 Under the proposed reform of the Act, ${ }^{71}$ however, a transfer for security will not be deemed made until the debtor has also acquired rights in the collateral. ${ }^{72}$ Since the new Copyright Act recognizes an author's copyright only from the time his work is fixed in a copy, ${ }^{73}$ a transfer of a copyright for security will not be deemed to have been made, for purposes of the proposed reform of the Bankruptcy Act, until that time. Consequently, the copyright subsisting in all work produced subsequent to the advancement of the funds that financed the production of the work will be deemed to have been transferred on account of antecedent debt, and a security interest in the copyright to work produced during the ninety-day period preceding bankruptcy will be voidable. ${ }^{74}$

69. Professor Countryman has argued that purchase money security interests in consumer goods may be voidable under $\$ 60(a)(6)$ on similar grounds. Countryman, Code Security Interests in Bankruptcy, 75 CoM. L.J. 269, 270-71 (1970). Purchase money security interests in consumer goods are perfected without filing, U.C.C. $\$ 9-302(1)$ (d), but filing is required to defeat subsequent good faith purchasers for value, $i d$. $\S 9 \cdot 307(2)$. Countryman argues that, since the "overt action" of filing is necessary to defeat a class of subsequent transferees that is larger than "buyer[s] in the ordinary course of trade," failure to file, even though it perfects against subsequent lienors, would postpone the date of transfer for purposes of $\S 60$ (a) to the eve of bankruptcy, rendering the transfer subject to avoidance as a preference under $\$ 60(\mathrm{~b})$. Countryman, supra, at $\mathbf{2 7 0 . 7 1}$. Countryman's theory has not yet been tested in any reported case.

There is no equivalent to $\$ 60(a)(6)$ in the proposed reform of the Bankruptcy Act. See Report of the Commission on the B.ANkRuptcy Liws of the United States, H.R. Doc. No. 137, pt. 1, 93d Cong., Ist Sess. 205 (1973) [hereinafter cited as Bankruptcy Commission REPORT].

70. See pp. 136-37 supra.

71. H.R. 8200, 95th Cong., 1st Sess., 123 CoNG. Rec. 6838 (daily cd. July 11, 1977) [hereinafter cited as Proposed Bankruptcy Reform]. The bill was passed by the House of Representatives on February 1, 1978. See 124 Cosc. Rec. H478 (daily cd. Feb. 1, 1978). The Senate version is S. 2266 , 95 th Cong., Ist Sess., 123 CoNG. REc. S18244 (daily ed. Oct. 31, 1977).

72. See Proposed Bankruptcy Reform, $\$ 547$ (c)(3) ("For the purposes of this scction, a transfer is not made until the debtor has acquired rights in the property transferred.")

73. See note 9 supra.

74. See Proposed Bankruptcy Reform $\$$ 547(b):

$[\mathrm{T}]$ he trustee may aroid any transfer of property of the debtor-

(1) to or for the benefit of a creditor;

(2) for or on account of an antecedent debt ....;

(3) made while the debtor was insolvent;

(4) made-

(A) on or within 90 days before the date of the filing of the petition ....

Note the change in the aroidance period from four months to ninety days. See Kennedy, The Report of the Bankruplcy Commission: The First Five Chapters of the Proposed New Bankruptcy Act, 49 INv. L.J. 122 (1971). 
An exception to the more stringent avoidance rules under the proposed reform is made for interests in inventory, which will be voidable only to the extent that an excess of the secured debt over the value of the inventory is reduced during the avoidance period. ${ }^{75}$ The definition of "inventory" in the proposed reform does not expressly exclude copyrights; ${ }^{i 6}$ nevertheless, the definition was borrowed from section 9-109 of the Uniform Commercial Code, ${ }^{77}$ and other provisions of the Code make clear that the term does not include copyrights. ${ }^{78}$

\section{A Proposal}

The creditor's problems originate with the statutory requirement of registration for constructive notice. Because of this requirement, a creditor financing a copyright production can neither ensure his priority under the new Copyright Act nor perfect his security interest under Article 9. His interest is thereby exposed to subordination both in and out of bankruptcy.

The legislative history of the Copyright Act suggests that the registration requirement was meant to facilitate title searches by allowing the searcher to follow the chain of title from the author ${ }^{70}$ and by relieving the searcher of the responsibility for looking beyond a single index..$^{80}$ In the case of completed, registered works of authorship, the requirement that transferees key their recordings to the initial registration as a condition of constructive notice is not burdensome. In the case of unregistered works, however, this requirement will work hardship on transferees by preventing them from giving notice of their rights in a copyright simply because the underlying work is not in a state fit to be registered. This hardship is unnecessary because a title searcher

75. Proposed Bankruptcy Reform, \$ 547(c); see Kronman, The Treatment of Security Interests in After-Acquired Property C'nder the Proposed Bankruptcy Act, 124 U. PA. L. REv. 110 (1975).

76. See Proposed Bankruptcy Reform, $\$ 547(\mathrm{a})(\mathrm{I})$ (defining "inventory" as "personal property leascd or furnished, held for sale or lease, or to be furnished under a contract for service, raw materials, work in process, or materials used or consumed in a business, including farm products such as crops or livestock, held for sale or lease").

77. The drafters of the relerant provisions had in mind "to effect coordination with the Uniform Commercial Codc," B.ANkruptcy Commission RePORT, supra note 69, pt. 2, at 169 , and the Bankruptcy Commission reported to Congress that the Bankruptcy Reform Act definition of inventory would differ from the Code definition only in that the former would include farm products, $i d$. at 173 .

78. Compare C.C.C. \$ $9 \cdot 109(4)$ (inventory consists of goods) with id. \$ 9-106 (general intangibles are not gootis), and $i d$., Comment (copyrights are general intangibles).

79. House Comm. on the Jupiciaky, 89 ru CoNG., Ist SEss., supra note 29, at 77.

80. This purpose is not brouglt out in the Icgislative history of the Act, but it is implicit in the limitation of constructive notice to documents revealed by reasonable searches under the title index. Sec Copyright Act of 1976, 17 U.S.C. app. $\$ 205$ (c)(1) (1976). 
can easily inform himself of the transferee's interest by an examination of the files at the Copyright Office. Copyright transfers are indexed by the names of the transferor and transferee, as well as by the title of the underlying work. ${ }^{81}$ It would not unduly burden searchers of title to unregistered works to examine the transferor index under the name of the party with whom he is dealing to determine the interests of other parties in the work.

The system would therefore both facilitate commercial transactions secured by copyrights and simplify copyright production financing with only a slightly greater burden on title searchers if the registration requirement were eliminated from section 205(c) of the new Copyright Act. ${ }^{82}$ Under this proposal, a transferee would still be required to key his recording into the registration system, but not before the work is registered. If he recorded before registration, he would take the risk, as he does now, that the work might be registered under a different title and his recording would be denied constructive notice. Preregistration transferees must continue to bear this risk so that post-registration title searchers can rely on the title index.

The proposed amendment would greatly simplify copyright production financing. Since recording the security transfer would give constructive notice of the security interest, recording would be the equivalent of filing an Article 9 financing statement and a perfected security interest would attach to the copyright of the work as it was produced. The perfected security interest would not be vulnerable to avoidance in bankruptcy by a trustee exercising his section 70 (c) lien creditor powers; nor would it be susceptible to non-recognition under section 60(a)(6), since the additional "overt act" of registration would no longer be required to obtain priority over "third persons other than a buyer in the ordinary course of trade." 83

Because recording would mark the moment in time after which subsequent lien creditors could no longer obtain superior rights, it would be deemed to mark the time of transfer for purposes of section 60 of

81. Letter from Chief of Information Center and Reference Center, Copyright Officc, to Author, Feb. 17, 1978 (copy on file with Yale Law Journal).

82. Specifically, section 205 (c) should be amended by adding the italicized language and deleting the bracketed language, as follows:

$\$ 205$ (c) Recordation as Constructive Notice.-Recordation of a document in the Copyright Office gives all persons constructive notice of the facts stated in the recorded document, but only if $[-(1)]$ the document, or material attached to it, specifically identifies the work to which it pertains so that, after the document is indexed by the Register of Copyrights and the work is registered, it would be revealed by a reasonable search under the title or registration number of the work [; and (2) registration has been made for the work].

83. Bankruptcy Act, $\S 60(a)(6)$, 11 U.S.C. $\S 96(a)(6)(1976)$. 
the Bankruptcy Act. If the creditor recorded before making his loan, the transfer would not be on account of antecedent debt and thus would not be voidable as a preference under section $60(b)$.

Under the proposed reform of the Bankruptcy Act, a transfer is not deemed to have occurred until the debtor himself has rights in the collateral. Since a statutory copyright does not subsist until the work itself is in esse, a transfer of a security interest in work produced after a loan is made will be deemed to have occurred on account of antecedent debt and will be voidable as a preference if bankruptcy occurs within ninety days of production of the collateral. Amending the new Copyright Act as suggested will not avoid this result, and financers of copyrightable work must expect to share with other creditors the value of work produced within the last ninety days preceding bankruptcy; however, this is the result intended by the drafters of the proposed reform and is not peculiar to security transfers of copyrights.

\section{Conclusion}

This modest proposal would not defeat the purposes of the new Copyright Act, the Bankruptcy Act, or the Uniform Commercial Code; on the contrary, it would support the policies behind these statutes. There are those who believe that the secured creditor is already unduly protected under the Bankruptcy Act, ${ }^{8 \pm}$ but the creditor secured by copyrights should not be singled out for reduced protection. The proposal would merely afford such creditors the rights in bankruptcy generally enjoyed by other secured creditors. It would further the Article 9 policy of facilitating secured transactions in all commercial property and, most importantly, it would put an end to the legal obstruction of security transfers of copyrights, making available an important mechanism for financing the creative efforts that the Copyright Act exists to protect. ${ }^{85}$

84. See, e.g., Countryman, sutpra note 69 , at $269-70$.

85. The constitutionally enunciated purpose of the Copyright Act is "to promote ... useful Arts, by sccuring for limited Times to Authors . . . the exclusive Right to their ... Writings." U.S. CoNsT. art. I, \$ 8, cl. 8. 